\title{
Mad Tales of Tollywood : Psychiatry in Bengali Cinema
}

Dr Ranjan Bhattacharyya ${ }^{1}$, Dr Sumita Bhattacharyya (Panda) ${ }^{2}$, Dr Supriya K Mondal ${ }^{3}$

${ }^{1} \mathrm{MD}$, DNB (Psychiatry). Assistant Professor \& Head of the Department, Deptt of Psychiatry, Murshidabad Medical College \& Hospital, West Bengal. Emailrankholders06@yahoo.co.in, ${ }^{2}$ DDVL. Institute of Post Graduate Medical Education and Research, Kolkata. Email : drsumita_ranjan@yahoo.com, MD (Psychiatry). ${ }^{3} \mathrm{RMO}$ cum Clinical Tutor. Murshidabad Medical College \& Hospital, West Bengal. Email : ima_ber_bengal@ hotmail.com

\section{ABSTRACT :}

There are reviews about portrayal of Psychiatry in Hollywood and Bollywood movies. Impact of cine media is extremely important in regional movies where actors and actresses are being worshipped as god. Initial stigmatization about madness is gradually changing to some strong social messages. Tollywood or Bengali movies have incorporated the mental illness way back from the era of Satyajit Ray and Riitwik Ghatak. The newer Bengali movies have extreme importance in spreading awareness and reducing stigma of mental illness.

Keywords : Tollywood movies, Mental Illness, Stigmatizarion, Social messages.

India makes more films than Hollywood. It's a very operatic film style with a lot of singing and dancing. 'Bollywood' films generally feature strong messages, often reinforcing traditional principles such as family values and acceptance by society. Similarly, 'Tollywood' films are not lagging behind, from melodrama, theatrical portrayal of middle class family life crisis to complex relationship problems of newer generation.

Critiques of individual films demonstrate the culture's approach towards mental illness and reflect the impact of culture on films and vice versa. Subjects covered include: cinema and emotion; attitudes towards mental illness; socio-economic factors and cinema in India; Indian personality, villainy and history; and psychoanalysis in the films of the 60 s.

We generally talk about mental illness in a Western context - the psychiatrist's definition of schizophrenia and manic depression, portrayal of possession states, trance and reincarnation too.

\section{Corresponding author :}

Dr Ranjan Bhattacharyya, MD, DNB (Psychiatry), Assistant Professor \& Head of the Department, Deptt of Psychiatry, Murshidabad Medical College \& Hospital, West Bengal, 29, Anandasree, Garia, Near Boral TB Hospital, Kolkata - 700084, Mob : $9433053389 / 9475556500$ Email : rankholders06@yahoo.co.in/drrbcal@gmail.com
In most of the films, psychosis is poorly defined, with people shown hearing and responding to voices. This depiction of mental illness is not solely the filmmaker's interpretation as these films were adapted from popular novels, which sold millions of copies at railway stations around India.

In terms of their portrayal of mental illness, Hindi films tend to represent the mentally ill as comedic supporting characters that add an amusing sideshow to, for example, the central 'love story'. There may occasionally be slapstick and jokes between two characters, so it will be interesting to perceive what subtext is conveyed to the audience." Part of his research will be to disentangle operatic license' - a characteristic of Hindi or Bengali cinema - from any portrayal of mental illness.

Mental illness is seen as an interaction between personality, seasons and food etc., rather than taking a biological or social approach. In India, people take a pluralistic approach to treating the mentally ill, incorporating Western treatment with visits to an Ayurvedic physician, and prayers at specific temples. The extent to which this is represented in films is a matter for investigation. 
Our very own, the Pather Panchali (1955) and Aparajito (1956) by Satyajit Ray portrayed the struggle of family and individuals against poverty, lack of proper medical care and natural calamities in villages. The sufferings and depression in villagers, superstitions, and cultural beliefs had been beautifully depicted by Manikbabu.

Deep Jweley Jai ${ }^{[1,2]}$ (Bengali : দীপজ্বেলে যাই, To light a lamp) was a Bengali movie directed by Asit Sen released in 1959. The film is based on Bengali short story titled, 'Nurse Mitra' by noted Bengali writer, Ashutosh Mukherjee. This is a story of a nurse in a psychiatric hospital, played by Suchitra Sen. Sen's character is a part of a team exploring new therapy for patients who have suffered emotional trauma. The approach taken by the team is to offer these individuals an emotional resort, which is where Sen's character plays her part. Her role is to act as a friend and a lover for the patient, but at the same time, refrain from any emotional involvement on her own part as her role is purely that of a nurse who is helping the patient recover. She has to repeatedly break the emotional attachments that she experiences because as a nurse, she is a part of therapy.

The movie looks at the neglected emotional trauma of this nurse who is used merely as a tool in the whole process of therapy. The movie ends by showing that the Sen is being admitted to the same ward where she used to be a nurse. The last words in the movie are uttered by Sen, who whispers out "I wasn't acting, I couldn't" indicating that she indeed fell in love with her patient! Also cast among others, were PahariSanyal, who plays a veteran doctor eager to explore new grounds, but hesitant of the human costs. Basanta Chowdhury plays as an artist and a lover-scorned.

The casting of the movie is as follows : Suchitra Sen as Radha, Basanta Choudhury as Tapas, Pahadi Sanyal as the psychiatrist and Anil Chatterjee acted as patient at mental asylum. The music was directed by Hemanta Kumar Mukherjee, and one of the songs, "Eiraattomaramar" (This night's just for you and me) has come to be regarded as one of the greatest and sensuous love songs ever sung in Bengali. The movie is regarded as one of the greatest movies exploring emotions of a relationship. Director Asit Sen (not to be confused with the actor-comedian Asit Sen) acted in the original Bengali film Deep JwéléJaai (1959) in a role, which was essayed by Dharmendra in Khamoshi.

Nayak : The Hero (1966). En route to Delhi to receive an award, a Bengali film star reevaluates his success through his fellow passengers, dreams and past experiences. The movie was directed by Satyajit Ray starring Uttam Kumar and Sharmila Tagore. A famous star of Bengali films, Arindam (Uttam Kumar), has been invited to the capital to receive a prestigious award. As all the flights are booked, he is forced to travel by a train from Calcutta to New Delhi. He is in a foul mood as the morning's papers are filled with his being involved in an altercation and his latest film is slated to become his first flop. The movie intensifies the stress among celebrities and their internal conflict, rejection hypersensitivity and coping strategies and application of immature defense mechanisms.

Mahanagar (1963) is a story, which portrays that life at home changes when a housewife from a middle-class, conservative family in Calcutta gets a job as a salesperson. In Abhijan (অভियान), a taxi driver attempts to introduce his cab service in rural Bengal against many odds. (150 mins.). Tin Kanya, (this anthology film was released in India as "Three Daughters". It was a feature composed of three episodes: The Postmaster - 56 min., Monihara - 61 min., and Samapti - 56 min. Monihara (The Lost Jewels) was left out from the international release probably due to concerns about length and subtitles not being ready for Monihara. The female characters that are central to the stories link the three episodes. Satyajit Ray adapted three short stories by Rabindranath Tagore as a tribute to the author to mark his birth centenary in 1961 . He also made a documentary "Rabindranath Tagore" as part of the celebrations. 
Baksa Badal (1970) : A hilarious romantic-comedy where two people have their luggage exchanged during a train journey. One of them (Soumitra) is a psychiatrist, and he develops a keen interest in knowing the other party (Aparna Sen). His experience as a psychiatrist helps him to understand the happy-go-lucky and pampered Aparna Sen and woo her love. Directo : NityanandaDatta. Writers : Bibhutibhushan Bandyopadhyay (story), Satyajit Ray (screenplay) Stars : Soumitra Chatterjee, Aparna Sen, Mumtaz Ahmed.

Agantuk : The Stranger (1991) - A well-off Indian family is paid an unexpected, and rather unwanted, visit by a man claiming to be the woman's long lost uncle. Pratidwandi (The Adversary) (1970) The historical background of the film Pratidwandi is set on the decade of a wide range of political turmoil in India. The huge influx of refugees during the partition of India and loss of economic activity in the hinterland of Kolkata resulted in the stagnation of the economy of Kolkata. The Naxalbari movement under Charu Majumdar saw splitting in the Communist party and an uprise in Naxalite movement inspired by the Maoist doctrine. Kolkata saw the most amounts of activities of the Maoist revolutionary group who constantly preached the local students and intellectuals. The main character Siddhartha's brother is one such example.

Devi focuses on a young woman, who is deemed a goddess when her father-in-law, a rich feudal landlord, envisions her as the Goddess Kali. Jana Aranya : The film portrays the hopelessness of the middle-class, educated, urban youth in modern India.

In Rajmahal, a married couple from Kolkata, Debashree (Anu Choudhury) and her husband Sumit (Abhishek Chatterjee), move to a village. There, they move into a supposedly haunted mansion. Deboshree then goes into the restricted room and finds out there was a dancer named Chandramukhi who had been killed by a zamindar (landlord in Bengali). Here she encounters Dr. Agni (Prosenjit Chatterjee) a psychiatrist. He comes to
Bakulpur from America. Agni analyses everything and finds out that Debashree is a psychiatric patient. She is suffering from a mental disorder (Dissociative identity disorder) and there is nothing called ghost.

Mayabazar is an interplay of illusions and reality. Bhooter Bhabishyat, though it is a ghost story, is meant to be a comic entertainer. The story is about a haunted house which is being pulled down and replaced with a swanky shopping mall. Apparently, the ghosts who belong to different era consider this as their home so what happens later on shapes the rest of the story. It is basically an interplay of illusions and reality.

Tabe Tai Hok : Saugata Ray Burman is an honest filmmaker. He tried his best to turn Tabe Tai Hok into a 'psychological thriller' and his honesty is evident. The obvious one was to explore, analyse and dig into the crazy painter Arjo's (Samadarshi Dutta) obsession for painting on women's bare bodies. The film opens with the idea of this atypical painter who uses the bare backs of beautiful women to express his creative artistic expression. He is very handsome and romantic looking so some of them fall for him and they often surrender to their basic passions.

In Charulata (1964), the lonely wife of a newspaper editor falls in love with her visiting cousin-inlaw, who shares her love for literature. Directed by Satyajit Ray and written by Rabindranath Tagorefrom the story "Nastaneer", Charu and Amal's feelings for each other move beyond those of a mentoring relationship as Charu begins a latent sexual attraction towards Amal.

The "Shabda" film starts showing Tarak's distraught wife who has taken him to a psychiatrist for treatment because she feels that he lives in a world of his own. The psychiatrist (Churni Ganguly) discovers that actually there is nothing wrong with Tarak's hearing ability. He just concentrates so much on background sounds that he does not pay attention to vocal sounds. While the doctor is speaking to him, Tarak is busy listening to the sounds of traffic in the streets or the sound of the Rubik's cube that she is holding 
in her hands. The doctor tries to convince Tarak that he has a serious problem and he needs treatment. But Tarak is not ready to believe that he has any problem. On the doctor's advice Tarak'swife takes him to Siliguri for a short holiday. Even there Tarak keeps listening to all the natural sounds like the twittering of birds or the gush of water in a mountain spring. On the trip, Tarak tries to convince his wife that there is nothing wrong with him. He just keeps thinking about sounds because that's his job.

In the Hemlock Society (2012), there is a strong insight into psychological dilemma about the primal existence of life. It reiterates the fact that you can 'shock someone by letting her know that death is impending and inescapable.' It is a dark comedy which successfully evokes an awareness of life. The comic element is used dexterously to bring out the fear of death.The plot revolves around a man who runs a school called "Hemlock Society" which teaches aspirants how to successfully commit suicide. It reiterates the fact that 'can you shock someone by letting her know that death is impending and inescapable.' It is a dark comedy which successfully evokes an awareness of life which is of course criticized by some forums. The comic element is used dexterously to bring out the fear of death.

Meghe Dhaka Tara (2013) is a Bengali film directed by Kamaleswar Mukherjee which is inspired from the life and works of Bengali film director Ritwik Ghatak. ${ }^{[2][3]}$ The entire film is in black and white except the last scene which has been shot in colour. ${ }^{[4][5][6]}$ In this film SaswataChatterjee plays the character of Nilkantha Bagchi and Ananya Chatterjee plays the role of Durga, Nilkantha's wife. Besides giving an account of Ghatak's life, the film also depicts the socio-political environment of contemporary West Bengal during the Tebhaga and Naxalite movements. The acting of Saswata Chatterjee as Nilkantha Bagchi was widely appreciated too. ${ }^{[2],[3],[4],[5]}$

The story of the film starts in 1969 and deals with Ritwik Ghatak's time spent in a mental asylum. It shows Nilkantha being admitted to mental asylum under the supervision of Doctor S. P. Mukherjee. S. P. Mukherjee learns that the Prime Minister of India knows Nilkantha and is fond of his works and may request the hospital authority to take special care of him. In the hospital a police officer sees Nilkantha and tells Doctor Mukherjee that he is a wasted drunkard. Another patient of hospital mocks Nilkantha as "disgraced intellectual". Even as he was undergoing treatment in the hospitals, he writes a play and stages it with other asylum patients.

Mrinal Sen was a close friend of Ghatak in real life. In this film Anindya Bose plays Sen's character. Abir Chatterjee plays Doctor S. P. Mukherjee, a psychiatrist.Inthisfilm, during aheated conversation, Nilkantha directly asks Doctor Mukherjee that does he recommend someone to perform dance (mujra) when the society is burning. Mumtaz Sorcar plays Supriya Devi's role. Supriya Devi portrayed Neeta in Ghatak's Meghe Dhaka Tara (1960).

Shabdo (Bengali : শব্দ, Sound) is a 2013 Indian Bengali film directed by Kaushik Ganguly. The film revolves around the life of Tarak, a foley artist of Bengali film. Tarak'sjob is to create ambient sounds for films, but, he gradually gets trapped in his own world, a world full of sound (i.e. Shabdo). It won the 60th National Film Awards for Best Feature Film in Bengali. ${ }^{[8]}$ The various roles played in this movie are as follows : Ritwik Chakraborty as Tarak Dutta, Raima Sen as Tarak's wife andChurni Ganguly as Psychiatrist.

The protagonist of the film is Tarak Dutta, a foley artist. He is so obsessed with his work that he loses his grip on words and his mind starts registering only foley sounds. The film starts showing Tarak's distraught wife who has taken him to a psychiatrist for treatment because she feels that he lives in a world of his own. The psychiatrist (Churni Ganguly) discovers that actually there is nothing wrong with Tarak's hearing ability. He just concentrates so much on background sounds that he does not pay attention to vocal sounds. While the doctor is speaking to him, Tarak is busy listening to the sounds of traffic in the 
streets or the sound of the Rubik's cube that she is holding in her hands. The doctor tries to convince Tarak that he has a serious problem and he needs treatment. But Tarak is not ready to believe that he has any problem. On the doctor's advice Tarak's wife takes him to Siliguri for a short holiday. Even there Tarak keeps listening to all the natural sounds like the twittering of birds or the gush of water in a mountain spring. On the trip, Tarak tries to convince his wife that there is nothing wrong with him. He just keeps thinking about sounds because that's his job. Tarak starts rebelling against the doctor and refuse to take treatment. Things come to a head, when the doctor tries to talk to him through headphones at this recording studio and Tarak breaks the mike in anger. With all her efforts gone to waste the doctor refers him to her professor (Victor Banerjee). Tarak loses his job and becomes quite depressed. He is always haunted by sounds and without his job he starts feeling dis-oriented. One day he tries to commit suicide. Finally, the doctors send Tarak to a rehabilitation center where he is made to listen to recorded human voices daily to get back to normal. ${ }^{[6],[7],[8]}$

By using films for teaching, one can get an interesting combination of entertainment and education. However, this method is not without its drawbacks. One has to be aware that commercial films are primarily made for entertainment and not education. They may not be made based on sufficient research and hence may reflect how an individual understands a mental illness rather than presenting a scientific understanding of the same. There may be distortion of data in order to make the stories more compelling and get better reviews and public attention. Similarly, diagnoses may not be always clear, in which case one has to always consider differential diagnosis and not ICD-10 or DSM IV categories. ${ }^{[9]}$ There is also a disadvantage of distortion and increased stigmatization of mental illness and the mentally ill in their portrayals in films that may lead to stronger stereotypes in the viewer's minds.
By addressing these issues, a broader aim of the project is to influence public attitudes and foster a more sympathetic understanding of mental illness. In India, families that care for the mentally ill need to realize that this is a genuine illness and not an act or a hysterical phenomenon. This narration may encourage film directors to modify their portrayal of the mentally ill and thus reduce the stigma attached to mental illness. The Tollywood cinema is a cultural and ideological force that creates and reinforces perceptions and attitudes in its viewers. As such, it could have a profound influence on the Indian population's attitudes to a mental health.

These movies had considerable mass-market appeal, and were seen by a significant slice of the Indian population. Undoubtedly, political factors colored the portrayal of mental illness. In the 80s and 90s, whilst India was amid much political restlessness, successful films made at that time included a psychopathic hero who always gets punished for his bad deeds. Cinema audiences would cheer on their wayward hero, despite knowing that retribution for his behaviour was inevitable.

Compared with Hollywood's portrayal of mental illness, Indian cinema is perhaps less enlightened. There are fewer Tollywood films that look at mental illness in a serious sympathetic way. ${ }^{[10]}$ Only one film discusses psychoanalysis at length and depictions generally refer to asylums or the traditional model of psychiatric hospitals. This gives an impression that Indian cinema may be 30 to 40 years behind Hollywood's image of psychiatry. This may again reflect differing social attitudes to mental illness. There are cultural differences where family contact, religion and pilgrimage may be the 'nonprofessional' ways of dealing with it.

\section{REFERENCES :}

\footnotetext{
1. "DEEP JWELEY JAI - Film Database - Movie Database". www.citwf.com. Retrieved 2008-10-23.

2. "Meghe Dhaka Tara review". ToI. 19 June 2013. Retrieved 19 June 2013.
} 


\section{Mad Tales of Tollywood}

3. Kamaleshwar Interview "Kamaleswar's next film is 'Meghe Dhaka Tara'". The Times of India. Retrieved 18 May 2013.

4. "Ritwik Ghatak Meghe Dhaka Tara". Telegraph, Calcutta. 16 June 2012. Retrieved 6 October 2012.

5. “মেঘে ঢাকা ঋত্বিক". Anandabazar Patrika. 28 November 2012. Retrieved 18 May 2013. (Bengali)

6. "Kaushik Ganguly's new film 'Shobdo'". The Times of India. Sep 8, 2011. Retrieved 24 December 2012
7. Dubai Review : Kaushik Ganguly's "Shobdo" (Sound)". Dear Cinema Review. Retrieved 24 December 2012.

8. 60th National Film Awards Announced" (PDF) (Press release). Press Information Bureau (PIB), India. Retrieved 18 March 2013.

9. Bhugra D. Teaching psychiatry through cinema. Psychiatr Bull. 2003; 27: 429-30.

10. Latest Bollywood Movie Kyunki :: Movie Review of Kyunki Movie :: story,cast and crew, stills of Kyunki Movie ::". www.salmankhan.net. Retrieved 2008-10-23. 